\title{
A PRIMEIRA ENCRUZILHADA DA DEMOCRACIA BRASILEIRA: OS CASOS DE RUI BARBOSA E DE JOAQUIM NABUCO
}

\author{
Christian Edward Cyril Lynch
}

\begin{abstract}
RESUMO
O advento do discurso liberal-democrático no Brasil ocorreu no momento em que as forças oligárquicas reuniram elementos para contestar a preeminência da Coroa sobre as estruturas políticas imperiais. A promoção da abolição da escravatura pela Coroa, contudo, gerou um curto-circuito na forma como, até então, liberalismo e democracia vinham sendo articulados. Nesse sentido, o contraste entre as posturas de Rui Barbosa e de Joaquim Nabuco é exemplar. A partir de uma perspectiva universalista normativa, Rui Barbosa seguiu a cartilha doutrinária liberal, correndo o risco de entregar o poder às oligarquias, ao passo que, por meio de uma análise sociológica, Nabuco preconizou o "despotismo esclarecido" da Coroa, capaz, segundo ele, de quebrar o poder oligárquico e implementar as necessárias reformas sociais. No presente artigo, a partir do recurso direto à documentação primária, analisa-se tal debate, não tanto para esmiuçar as diferenças entre os dois políticos, considerados em suas personalidades individuais, mas para ilustrar uma questão mais ampla, que remonta ao percurso da construção da democracia brasileira. A comparação entre os discursos de Rui Barbosa e Joaquim Nabuco ilustra o dilema entre priorizar reformas políticas e priorizar reformas sociais, em um contexto em que elas pareciam claramente excludentes. $O$ debate ajuda ainda a compreender os impasses da trajetória democrática no Brasil, premida entre o liberalismo oligárquico e a ampliação autoritária do espaço público.
\end{abstract}

PALAVRAS-CHAVE: democracia; liberalismo; modernização; Rui Barbosa; Joaquim Nabuco; reformas políticas; reformas sociais.

\section{INTRODUÇÃO}

O objetivo do artigo é o de chamar a atenção para a diversidade dos discursos de modernização democrática que legitimaram as campanhas políticas das duas últimas décadas da monarquia brasileira - as da eleição direta, da abolição da escravatura, do federalismo e da república. Debruço-me especificamente sobre os mais destacados liberais do período - Rui Barbosa (1849-1923) e Joaquim Nabuco (1849-1910) - com o fito de examinar por quê, formados na mesma fôrma anglófila e pertencendo à mesma geração e ao mesmo grupo do Partido Liberal, ambos atritaramse ou divergiram durante aquelas campanhas e romperam por dez anos. Rui Barbosa era o defensor por excelência da modernização política: para ele, as reformas políticas eram um imperativo civilizador e, como tal, elas deveriam ser impostas de cima para baixo, com ou sem a monarquia. Joaquim Nabuco, ao contrário, entendia que as reformas políticas teriam pouco ou nenhum alcance enquanto a maioria da população continu- asse excluída da vida cívica pela dependência em relação a senhores e patrões. Do contrário, não haveria opinião pública capaz de conferir substância às instituições democráticas, que acabariam por esgarçar o abismo entre elas e o país real. Daí porque Nabuco priorizou reformas que alterassem a estrutura fundiária nacional, a fim de criar uma classe de trabalhadores educados e pequenos proprietários. A realização dessas reformas dependia, entretanto, da preservação das estruturas políticas monárquicas, atacadas por Rui Barbosa e pelos republicanos como autoritárias.

O que interessa aqui não é tanto voltar a esmiuçar as diferenças entre os dois políticos, considerados em suas personalidades individuais - o que já foi feito por autores como Luiz Viana Filho (1949) e Levi Carneiro (1954) -, mas fazê-lo de uma maneira que ilustre uma questão mais ampla, que remonta ao percurso da construção da democracia brasileira, e isso a partir do recurso direto à documentação primária. A comparação entre os discursos de Rui Barbosa e Nabuco ilustra o dile- 
ma entre priorizar reformas políticas ou reformas sociais, num contexto em que elas pareciam claramente excludentes.

\section{O QUADRO IDEOLÓGICO DO II REINA- DO E O LIBERALISMO RADICAL}

O modelo institucional do II Reinado era o do governo parlamentar britânico, mas filtrado pelos teóricos franceses e pela prática política da "Monarquia de Julho", caracterizados pelo unitarismo, pela justiça administrativa e por um sistema parlamentar que, com todas as suas limitações, permitia uma alternância razoável dos partidos no poder. Sua adaptação ao Brasil, no final da década de 1830, originou o modelo político saquarema, isto é, um governo parlamentar e centralizador tutelado pela Coroa. Os senadores e fundadores do Partido Conservador, Bernardo Pereira de Vasconcelos (1795-1850) e Paulino José Soares de Souza, o Visconde do Uruguai (1807-1866), que haviam sido os principais artífices e defensores do modelo, justificavam-no por meio de dois argumentos básicos. O primeiro era o da necessária preeminência do Imperador sobre o Parlamento, na medida em que a monarquia constitucional havia sido aclamada diretamente pelo povo antes da reunião da Constituinte; por isso mesmo, era o Imperador, e não a representação parlamentar, o defensor perpétuo do Brasil. Era um argumento, portanto, de contornos bonapartistas (cf. LYNCH, 2005).

O segundo motivo residia na invertebração da sociedade nacional, cujo atraso intelectual e pobreza refletiam-se na vacuidade da vida política e no individualismo de seus políticos. A ausência de uma opinião pública consistente tornava impraticável um governo parlamentar à inglesa, isto é, estruturado de baixo para cima, a partir de eleições honestas. Daí que, na falta de uma base eleitoral em que o sistema pudesse apoiar-se, ele só pudesse organizar-se de cima para baixo, isto é, a partir da legitimidade democrática de que a monarquia hereditária havia sido investida. Os saquaremas pensavam que seria, dessa forma, possível ao governo organizar a política para impor o interesse público sobre o particularismo e submeter os potentados rurais, criando a ordem e difundindo, a partir da Corte, a civilização pelas províncias (MATTOS, 1994, p. 153). A prerrogativa da Coroa na escolha de senadores e conselheiros de Estado vitalícios ajudava, inclusive, a forjar um quadro político e burocrático autôno- mo, imune às fraudes que marcavam as eleições para deputados; e eram naqueles, portanto, que a administração tinha de fiar-se.

Entretanto, o modelo saquarema começou a ser seriamente contestado a partir de 1867-75, quando a segunda reforma eleitoral inglesa e a consolidação da república francesa apontaram inequivocamente para a democratização dos direitos políticos na Europa ocidental, e as teorias do governo misto e do governo parlamentar, definidas pelos teóricos da "Monarquia de Julho", foram substituídas pelas da democracia e do parlamentarismo. Referência a todas as monarquias constitucionais, não restava agora mais dúvidas de que, ao contrário do que sustentavam até então os teóricos do governo misto, vigia na Inglaterra um parlamentarismo democrático, que fizera da câmara eletiva o único órgão legitimado para formar e demitir governos, devendo a Coroa apenas reinar e não governar. O jornalista e arauto do parlamentarismo inglês, Walter Bagehot (1826-1877), explicava, em sua obra A constituição britânica, que dali por diante a Coroa e a Câmara dos Lordes deveriam ser vistas apenas como as partes dignificadas da Constituição inglesa, fachada solene e aparatosa do governo monárquico, por detrás da qual escondiam-se suas partes eficientes - Câmara dos Comuns eletiva, gabinete responsável, Primeiro-Ministro executivo. Eram estes os órgãos modernos e democráticos que se encarregavam de governar o país por trás da decorativa fachada histórica (BAGEHOT, 2003, p. 208).

Esse momento coincidiu ainda, no Brasil, com a grita das oligarquias provinciais contra a pressão exercida - a título de civilizar os sertões (COSER, 2005, p. 239) - pelo governo nacional e a favor de uma maior autonomia política e administrativa, de que foi veículo por excelência a obra do Deputado liberal alagoano Aureliano Tavares Bastos (1839-1875), autor de Os Males do Presente e as Esperanças do Futuro, das Cartas do Solitário e de A Província. Daí a campanha de reformas promovida pelos liberais, que incluía a eleição direta, a descentralização, a autonomia do Judiciário, a extinção do contencioso administrativo, a temporariedade do Senado, a neutralização do poder Moderador e, de forma mais vaga, a abolição da escravatura.

Nesse quadro de contestação da centralização política e do ascendente da Coroa sobre o Parlamento, a ala esquerda do Partido Liberal brasileiro 
adotou uma forma ainda mais exaltada de liberalismo - a do radicalismo que, combinando pureza de princípios e pragmatismo estratégico, exprimia-se numa linguagem idealista e desabusada. Ao exemplo de seus homólogos franceses - principalmente Jules Simon (1814-1896), seu principal doutrinador -, os radicais acreditavam representar uma consciência pública democrática gerada pelo conhecimento científico da filosofia da história e propunham, por isso, romper as fórmulas de transigência que caracterizavam, até então, a política liberal. Para além dos meramente liberais, os radicais pregavam a separação entre Igreja e Estado, a democratização do sufrágio, a instrução pública universal - medidas necessárias a uma sociedade moderna e, como tal, autenticamente liberal (SIMON, 1868, p. 4).

O liberalismo radical era a linguagem de Rui Barbosa e de Joaquim Nabuco, eleitos deputados gerais, em 1878, aos 29 anos de idade, pela Bahia e por Pernambuco, respectivamente. Embora tivessem vínculos com a aristocracia rural de suas províncias, os radicais preferiam tentar apoiar-se nos setores altos e médios das cidades, onde viam uma promessa de modernidade e opinião pública. Preocupados com o atraso do Brasil, eles acreditavam que pela maior mobilização da opinião pública seria possível acelerar o tempo histórico, devendo a política transcender as arenas parlamentares por meio de conferências e comícios. Rui Barbosa explicava: "Toda reforma é a preparação de uma reforma superior; todo progresso, a determinante de um progresso futuro" (BRASIL. CÂMARA DOS DEPUTADOS, Anais da Câmara dos Deputados, 21.jun.1880). Entretanto, os liberais urbanos comprometiam-se a lutar dentro da lei. Em vez de uma força de subversão, seu radicalismo era assim "um elemento de ordem, um princípio de paz, um ponto permanente de apoio ao gênio do progresso moderado contra os empuxões opostos da reação retrógrada e das exaltações revolucionárias [...], equilibrando o desenvolvimento do Estado entre essas exagerações extremas” (BARBOSA, 1950, p. 4).

Constituindo-se no primeiro segmento político brasileiro a apresentar identidade sociológica com aqueles que portavam valores liberal-democráticos na Europa, eles buscaram reforçar o peso do eleitorado das cidades por meio da atuação doutrinária pela imprensa e da fundação de associações civis, como a Confederação Abolicionista e a Sociedade Central de Imigração. Do ponto de vista da reorganização do Estado, conforme o parlamentarismo democrático de Bagehot, os radicais não tinham medo de mexer na Constituição de 1824 a fim de colocar o Brasil à altura do século. Como dizia Rui Barbosa, a Carta não era "um Talmude, onde o texto, materialmente obedecido, exerça a menos inteligente e a mais servilizadora das tiranias” (idem, p. 95). O jovem Nabuco não destoaria: “A nossa Constituição é um grande maquinismo liberal, e um mecanismo servido de todos os órgãos de locomoção e de progresso, é um organismo vivo que caminha e adapta-se às funções diversas que em cada época têm necessariamente que produzir" (NABUCO, 1983, p. 98).

Do ponto de vista da doutrina social, os liberais urbanos absorviam em diferentes graus o impacto do novo liberalismo britânico, teorizado por Thomas Hill Green (1836-1882) e capitaneado pelo Primeiro-Ministro William Gladstone (1809-1898), chefe dos liberais ingleses. Para enfrentar os desafios da democratização, o maior do quais era a insatisfação do operariado com a desigualdade social e sua atração quase irresistível pelo socialismo, o novo liberalismo adotava uma concepção mais positiva do Estado, admitindo a limitação do direito de propriedade e de livre contratação em favor do interesse daqueles que, com seus salários, não tinham acesso aos confortos necessários a um padrão de vida razoável. Não por acaso, o novo liberalismo passou a bater no domínio da antiga aristocracia de sangue e a recorrer cada vez mais à noção de pátria, deixando à sombra o antigo universalismo, a fim de justificar uma maior preocupação com a igualdade material. Cabia, pois, ao Estado remover os obstáculos ao desenvolvimento humano para permitir a um número crescente de indivíduos o gozo das garantias liberais, o que passava necessariamente pela formação de uma sociedade de pequenos proprietários (LASKI, 1973, p. 174). No Brasil, foi a emancipação dos escravos que passou a ser vista pela maioria dos liberais urbanos como a reforma social por excelência. Os mais exaltados dentre eles eram ainda atraídos pelo exemplo da reforma fundiária promovida por Gladstone, na Irlanda, território até então dividido em enormes latifúndios, cujos donos viviam em Londres à custa do trabalho de lavradores desprovidos de qualquer proteção - situação que parecia, a esses liberais, assustadoramente semelhante à do Brasil (CARVALHO, 1998, p. 180). 
Contextualizado o quadro ideológico em que Rui Barbosa e Nabuco fizeram sua educação política, passo a examinar agora seus comportamentos durante as quatro grandes campanhas democráticas que tiveram lugar durante a década de 1880: a reforma eleitoral, a abolição da escravatura, a federalização das províncias e a república.

\section{A REFORMA ELEITORAL: LIBERALISMO \\ ILUSTRADO E DEMOCRACIA ILETRADA}

A primeira campanha foi a da reforma eleitoral. Para os liberais, era a introdução da eleição direta que regeneraria o sistema representativo brasileiro. Acabando com as fraudes eleitorais, a reforma fortaleceria a dependência do governo em relação à Câmara dos Deputados, acabaria com as intervenções do gabinete nas eleições e com a necessidade de a Coroa periodicamente alternar os partidos no poder. Numa palavra, a reforma eleitoral renovaria o sistema político, permitindo a prática do parlamentarismo à inglesa no Brasil. Pelo fato de que ela implicaria, porém, na redução do enorme eleitorado, de predomínio rural, que formalmente votava no país, a reforma passou a ser reivindicada pela lavoura, na década de 1870, como um meio de organizar e consolidar sua influência eleitoral por meio de um parlamentarismo aristocrático, que em seu benefício eliminasse a autonomia do Estado e evitasse a imposição de novas leis abolicionistas, como ocorrera por ocasião da Lei do Ventre Livre. Privando os analfabetos do voto e excluindo os pobres restantes por meio da elevação do censo pecuniário, os fazendeiros poderiam melhor coagi-los aos rigores do trabalho rural - sob pena de expulsá-los da terra: “A eleição direta, com censo alto”, explicava um deles, "desobrigará o lavrador de manter em suas terras vadios ou parasitas, que entendemse com direito de ser sustentados em troca do voto que vão dar; e esses se tornarão trabalhadores” (FUNDAÇÃO CASA DE RUI BARBOSA, 1988 [1878], p. 52).

A crise de legitimidade do modelo político saquarema e a pressão da aristocracia rural tornaram a reforma eleitoral uma aspiração dos setores agrários dos dois partidos, obrigando o Imperador Dom Pedro II (1825-1891) a despachar os conservadores e a chamar os liberais, em 1878, depois de dez anos de oposição destes. Sintomaticamente, o primeiro gesto político do novo Primeiro-Ministro, o Visconde de Sinimbu (18101906), foi a convocação de um congresso agrí- cola no Rio de Janeiro, composto de representantes de toda a lavoura do sudeste, diante dos quais comprometeu-se a governar de acordo com suas reivindicações. Matavam-se, assim, dois coelhos numa única cajadada: excluindo das urnas "a escória do povo” (idem, p. 48), “a massa ignorante que tem concorrido para falsear a representação nacional” (idem, p. 196), “a liberdade política” seria restaurada, consolidando-se o governo do país nas mãos da aristocracia rural; ao passo que, destituídos do trunfo que lhes permitia barganhar, os pobres se veriam obrigados a trabalhar na lavoura, sob pena de serem expulsos da terra (idem, p. 32). Em outras palavras, o discurso democrático, que na Europa justificava a reforma eleitoral a partir da necessidade de ampliação da esfera pública, prestava-se no Brasil para legitimar a eliminação da autonomia do Estado, em benefício exclusivo da grande propriedade rural, que faria dele um instrumento de classe; ou seja, o discurso democrático era empregado aqui, pela lavoura escravocrata, para aristocratizar o sistema político (cf. LYNCH, 2007a).

Por isso mesmo, quando o governo apresentou seu projeto, deputados liberais como José Bonifácio, o Moço (1827-1886) e Joaquim Nabuco deram-se conta de que, sob as vestes do discurso parlamentarista, a intenção era a de oligarquizar o sistema político para obstRui Barbosar o movimento abolicionista. Eles romperam então com o gabinete Sinimbu e o acusaram de trair os ideais democráticos, por querer, segundo Nabuco, "não alargar o voto, não reformar a Constituição no sentido liberal, mas no sentido reacionário, tirando dos seus alicerces a primeira pedra das nossas liberdades. E para quê? Para constituir-se uma aristocracia!” (NABUCO, 1983, p. 108); "Ao passo que em todo o mundo civilizado a democracia celebra as suas festas populares pelo alargamento do voto, que tende a tornar-se universal”, protestava José Bonifácio, “queremos celebrar as nossas, condenando ao ilotismo político a máxima parte da população de um país livre” (ANDRADA E SILVA, 1978, p. 68).

No entanto, Rui Barbosa era favorável ao projeto, alegando ser preciso dar "margem ao patriotismo, à ilustração, à independência, à fortuna, à experiência” (Rui Barbosa apud PORTO, 2002, p. 100). Como líder do governo, ele escreveu um discurso de 120 páginas para convencer a oposição de que o novo censo pecuniário excluiria ape- 
nas os indigentes e os mendigos, e que a eliminação dos analfabetos era um imperativo do sistema representativo, que precisava deixar de ser uma "democracia selvagem" para se tornar uma "democracia racional”. E concluía: “A soberania da consciência, a soberania do discernimento (que outra não é a do projeto), vale, seja como for, um pouco mais que a soberania analfabeta, a soberania néscia do inconsciente" (BRASIL. CÂMARA DOS DEPUTADOS, 10.jul.1879). Nabuco voltou à tribuna para sustentar que não podia ser democrático um projeto que reduzia o eleitorado em vez de alargá-lo, o que levou Rui Barbosa a contestar "o irrefletido liberalismo dos nossos antagonistas" e a defender novamente o governo, sob a alegação de que a redução do eleitorado seria compensada pela melhoria da qualidade do voto (BARBOSA, 1952, p. 116).

Conforme previa Nabuco, a nova lei - que quase se chamou-se Lei Rui Barbosa - reduziu o eleitorado em dez vezes e consolidou o sistema político nas mãos da lavoura, substituindo o antigo modelo político saquarema por um parlamentarismo aristocrático. Redator da nova lei, Rui Barbosa foi reeleito Deputado; todavia, já engajado na luta contra a escravidão, Nabuco não teve a mesma sorte. Não por acaso, ele acusou então a nova lei - a lei Saraiva - de ter feito do Parlamento "um verdadeiro Congresso Agrícola" (NABUCO, 1988b, p. 32).

\section{A REFORMA SOCIAL: IMPERATIVO CIVILIZADOR E FORMAÇÃO NACIONAL}

A segunda campanha em que Rui Barbosa e Nabuco engajaram-se foi a da abolição da escravatura. Decidido a apoiar o movimento, em 1884, o Imperador chamou à Presidência do Conselho o Senador liberal Manuel Pinto de Sousa Dantas (1831-1894), padrinho político de Rui Barbosa. Até então, a contribuição de Rui Barbosa à causa havia sido mínima, mas seu dever partidário e sua convicção particular levaram-no a escrever esta que alguns consideram a segunda maior contribuição intelectual feita à causa abolicionista (MORAN, 1973, p. 52). Incumbido novamente de relatar o projeto de lei, o Deputado baiano escreveu um parecer de 180 páginas, denominado Emancipação dos escravos, em que triunfava pelo assombroso conhecimento de Direito Comparado, pela erudição e pela dialética retórica (cf. BARBOSA, 1988). Para além da injustiça da escravidão, o ponto central de sua crítica a ela residia no seu anacronismo do ponto de vista da filosofia da história como progresso. A escravidão deveria ser eliminada como regime de trabalho, antes de tudo, por ser a maior causa do vergonhoso atraso do Brasil entre as nações civilizadas. Seus argumentos, por sua vez, eram organizados pela necessidade de refutar de forma paciente e erudita pelo menos uma dúzia de argumentos jurídicos, políticos e econômicos daqueles que se opunham ao projeto de Dantas.

Rui Barbosa era, antes de tudo, um espírito jurídico. Para ele, a forma da exposição resumiase essencialmente na contestação retórica dos argumentos do oponente, isto é, depois de seus ideais universais de justiça, era principalmente a necessidade de opor-se e de combater-se pessoas e grupos que dava a forma e o lugar de suas posições políticas. Recorrendo não apenas às opiniões pretéritas de seus opositores ou de antigos líderes dos dois partidos, mas também a diversas estatísticas e tabelas - indicativas da cientificidade das conclusões abolicionistas - e a obras de Direito Internacional Comparado, que se encarregavam de apontar a injustiça e o isolamento do Brasil, Rui Barbosa apontava, uma a uma, as contradições e insubsistências da oposição, completando o trabalho com abundantes citações de Alexis de Tocqueville, John Stuart Mill, Charles Darwin e Leroy Beaulieu, entre outros intelectuais, políticos, economistas ou cientistas contrários à escravidão (idem). As reformas sociais efetuadas na Irlanda por Gladstone, entretanto, eram invocadas por ele, menos como algo bom em si mesmo do que como argumento destinado a desmentir a acusação de que o projeto abolicionista não era liberal e sim socialista. Em outras palavras, serviam mais para negar a propositura adversária do que para fundar uma política social, tanto assim, que, depois de abolida a escravidão, Rui Barbosa abandonou a agenda das reformas sociais para retomar a das reformas políticas, que antes já haviam-no ocupado.

Por sua vez, Nabuco aproveitou a derrota eleitoral para escrever $O$ abolicionismo, obra que transcendeu o nível de propaganda para tornar-se a primeira obra-prima de nossa literatura social. Ao partir de uma concepção de nação mais larga do que aquela da elite brasileira, Nabuco entendia a abolição não apenas como uma exigência da marcha civilizadora da história, mas como um imperativo da construção nacional que, para cons- 
tituir-se como tal, precisava incorporar os pobres e os escravos. Seu olhar sociológico transformou a escravidão numa verdadeira infra-estrutura da sociedade brasileira, responsável pelo monopólio da propriedade e da política por uma minoria de senhores e patrões que submetia o mundo dos trabalhadores ao seu arbítrio e impedia o surgimento de uma classe de trabalhadores livres. Haja vista que não existia uma nação formada apenas de senhores, ou seja, de uma única classe - a patronal -, a formação política da nacionalidade brasileira dependia da superação dessa dicotomia entre mundo do trabalho e mundo da cidadania, cujo primeiro passo estava na extinção da escravatura e no reconhecimento da dignidade e da juridicidade do mundo do trabalho. Por isso mesmo, não bastava acabar com a escravidão, sendo preciso ainda eliminar a sua obra: a abolição total deveria ser a primeira de uma série de reformas sociais necessárias à elevação do povo brasileiro ao grau de civilização que se esperava dele (cf. NABUCO, 1988a).

Advogando medidas como a reforma agrária, o imposto territorial e o fim da escravidão, o objetivo do "partido da reforma social” (NABUCO, 1988b, p. V-VI) era combater a reação aristocrática em andamento, isto é, a "tentativa para fazer retroceder o curso da democracia entre nós e proclamar a política de desconfiança contra o povo, que eu quero ver de todos os modos elevado na sua própria estima e aos nossos olhos e educado na escola de todos os direitos e da mais completa igualdade” (idem, p. 34). Ou seja, Nabuco levava a sério o caráter social do novo liberalismo britânico, vendo na intervenção do Estado no mundo da economia - a fim de reduzir as desigualdades e desconcentrar a propriedade - um requisito essencial para desenfeudar o povo do domínio oligárquico e liberalizar o conjunto da sociedade brasileira, e não apenas suas elites.

\section{V.ACAMPANHAFEDERALISTA: MONARQUIA} LIBERAL E MONARQUIA DEMOCRÁTICA

A terceira campanha de que Nabuco e Rui Barbosa participaram foi a da federalização das províncias. A iniciativa federalista coubera ao primeiro, em 1885. Para Nabuco, o federalismo era então um meio de pressionar a Coroa a retomar a agenda abolicionista, que ele julgara estacionada, e de permitir às províncias um meio de fazeremno por si mesmas, dando-lhes autonomia face ao gabinete conservador que retornara ao poder. De volta à Câmara, quando Rui Barbosa era dela expelido, Nabuco justificou seu projeto de federação com os mesmos argumentos de Tavares Bastos: a federação era uma demanda histórica e um imperativo geográfico que acomodaria as divergências de interesses provinciais e permitiria seu desenvolvimento contra a tendência crescente de absorção pela burocracia central; no entanto, a nova federação deveria preservar a força do governo nacional e assegurar que os governos provinciais não fossem engolidos por suas oligarquias. O projeto não foi julgado digno de deliberação; contudo, ao voltar ao poder, em 1889, o Partido Liberal estava decidido a cumprir um extenso programa de reformas decidido na sua primeira convenção.

O reformismo liberal visava a fazer frente à propaganda federativa republicana, que crescera enormemente depois de 13 de maio, com a adesão maciça da aristocracia rural, descontente com a abolição sem indenização. Com efeito, a lavoura estava ansiosa por governar suas províncias e temerosa de que viessem mais reformas sociais, tais como as anunciadas pela Fala do Trono, de 1889, que anunciara a desapropriação de terrenos marginais às estradas de ferro para dividi-las e entregálas aos imigrantes e aos escravos libertos (JAVARI, 1993, p. 511). A primeira das reformas anunciadas pelo novo gabinete, do Visconde de Ouro Preto (1836-1912), era uma descentralização políticoadministrativa marcada pela desconcentração tributária e pela escolha dos presidentes de província segundo os mesmos critérios da escolha dos senadores - eleição popular provincial, lista tríplice dos mais votados e escolha do Imperador. A proposta fazia concessões às demandas federalistas das oligarquias mais poderosas, como a paulista e a gaúcha, sem chegar aos seus extremos, julgados geralmente perigosos à unidade nacional.

O fato de o Visconde de Ouro Preto não ter abraçado o federalismo motivou protestos de Nabuco e de Rui Barbosa. No entanto, ao reapresentar seu projeto federalista à Câmara dos Deputados, em 1888, o Deputado pernambucano apresentava uma inflexão em relação à sua primeira tentativa, de três anos antes. A federalização das províncias era agora vista menos como um bem em si mesmo do que como uma concessão necessária para salvar a monarquia contra o assalto da aristocracia rural, que, depois da Lei Áurea, aderira à república e, com suas oligarquias 
estaduais, com o separatismo e a ditadura militar, ameaçava o Brasil. O histórico de serviços prestados pela monarquia - a independência política por Pedro I (1798-1834), a construção do Estado por Pedro II e a formação da nacionalidade pela Princesa Isabel (1846-1921) - teriam demonstrado que a Coroa podia ser um poderoso veículo de transformações políticas e sociais e que, como tal, era uma arma indispensável num sistema representativo bloqueado pelo exclusivismo da grande propriedade rural, que monopolizava a esfera pública.

A resistência das oligarquias rurais das províncias, organizadas politicamente pela reforma eleitoral, e as dificuldades dos abolicionistas em avançarem num ambiente de frágil opinião pública, diante do peso esmagador do campo, levaram Nabuco à conclusão de que os verdadeiros democratas estavam privados, no Brasil, de um meio liberal de realização das reformas: o apelo a um espaço público nacional. Para que as reformas sociais pudessem prosseguir, a preservação da forma monárquica tornara-se uma condição sine qua non, pois só ela tinha força para enfrentar a aristocracia rural, e era essa mesma a razão pela qual o republicanismo crescia velozmente, depois de 13 de maio (BRASIL. CÂMARA DOS DEPUTADOS, 8.ago.1888).

Para Nabuco, não dispondo mais de qualquer esfera de poder alheia à voracidade das elites, a república brasileira não haveria de constituir governo da coisa pública, mas da coisa privada das elites agrárias, que a monopolizariam para melhor oprimir o povo em seu próprio nome. Porque "as oligarquias republicanas, em toda a América, têm demonstrado ser um terrível impedimento à aparição política e social do povo”, Nabuco declarava estar "com o povo defendendo a Monarquia, porque não há na República lugar para os analfabetos, para os pequenos, para os pobres" (idem, 7.jun.1889). Nesse ponto, se o olhar sociológico de Nabuco coincidia com o de outros estadistas brasileiros da tradição conservadora, como José Bonifácio de Andrada e Silva (1763-1838), o Marquês de Caravelas (1768-1836), Bernardo de Vasconcelos e o Visconde de Uruguai, ele deles diferenciava-se pelo fato de que pretendia aproveitar a autonomia e a centralidade da Coroa antes para constituir a nação do que o Estado, tarefa que julgava já concluída.

Já Rui Barbosa rompera com as lideranças do partido para lançar-se em uma feroz campanha jornalística pela federalização das províncias. Para ele, a proposta do Visconde de Ouro Preto era "uma transação, que de modo nenhum satisfaz as atuais aspirações do país, nem se contrapõe ao movimento republicano como um regime capaz de neutralizá-lo" (FUNDAÇÃO JOAQUIM NABUCO, Arquivo Joaquim Nabuco). O fato de ter sido voto vencido na convenção do partido não só não o impelia a moderar sua conduta, como tornava-o cada vez mais audaz no seu antagonismo demolidor: à medida que perdia lugar em seu partido, ele defendia suas propostas com mais intolerância e paixão, o que enfraquecia suas possibilidades de voltar a ocupar cargos e, novamente, alimentava sua radicalização (GONÇALVES, 2000, p. 48).

Rui Barbosa não apenas se recusara a integrar o ministério como se declarara em oposição a ele, passando a fustigá-lo e ao próprio regime monárquico em seus artigos diários no Diário de Notícias. Para Rui Barbosa, o federalismo tinha de vir com ou sem a monarquia; por isso, negava à Coroa todos os méritos que lhe conferia Nabuco na abolição da escravatura, atribuindo-os às rebeliões escravas e à opinião pública alimentada pela propaganda. Rui Barbosa desconfiava ainda do reformismo social do Imperador, que anunciara, na Fala do Trono, uma reforma fundiária destinada a assentar os ex-escravos e os imigrantes. Para Rui Barbosa, poderia ser apenas um factóide destinado a cegar os libertos "desvairados pela propaganda redentorista” e a fazê-los apoiarem o futuro reinado reacionário de Dona Isabel e de seu marido, o Conde d'Eu (BARBOSA, 1956, p. 137). Aludindo ao colega pernambucano e aos "deslizes do seu espírito”, Rui Barbosa criticava aos que viam na Coroa um instrumento da reforma social e negava-se a crer que Nabuco tornara-se "um hipotecado pelos vínculos da abolição aos projetos do terceiro reinado" (idem, p. 83).

O mais espantoso é que Rui Barbosa, a despeito de sua linguagem desabrida, ainda declarava-se monarquista. As palavras demolidoras à monarquia brasileira destinavam-se apenas, segundo ele, a persuadir a Coroa a enquadrar-se no figurino parlamentarista democrático de Bagehot, a conseguir "a monarquia representativa na sua pureza”. Na verdade, ele nunca aceitou a idéia de que a autonomia do Estado imperial fosse antes efeito do que causa das dificuldades do sistema 
representativo no Brasil, nem a tese de que as intervenções do poder Moderador eram necessárias para evitar o domínio oligárquico de um partido único. Para o político baiano, admiti-las faria dele um conservador da "escola reacionária" do Visconde de Uruguai (BARBOSA, 1978, p. 307). A boa hermenêutica constitucional impunha que, numa sociedade democrática e liberal, as atribuições monárquicas fossem interpretadas como mera fachada da monarquia constitucional brasileira e que, na prática, somente pudessem ser exercidas por uma autoridade responsável, isto é, o gabinete. Elas não passavam de "fórmula reverencial, em homenagem ao papel simbólico da Coroa” (idem, p. 41). Não havia, pois, meio termo: o exercício do poder Moderador conforme a vontade do Imperador não passava de exercício ilegítimo do poder pessoal.

VI. OS SENTIDOS DAREPÚBLICA:AFORMAS

E A SUBSTÂNCIA DA DEMOCRACIA NO BRASIL

Por fim, a última questão política em que se envolveram Rui Barbosa e Joaquim Nabuco foi a da república, que os levou a romperem relações por dez anos. Para o autor de Cartas da Inglater$r a$, liberal embebido na fôrma inglesa e na filosofia da história como progresso da liberdade, havia apenas um tipo de governo legítimo a ser ensaiados para além da monarquia parlamentarista inglesa - a república federativa e presidencialista norte-americana, que era a outra face da mesma tradição. A mudança, segundo ele, seria "de um regime constitucional para outro, igualmente constitucional: da monarquia à inglesa para a república à americana, de instituições já liberais para outras mais adiantadas em liberdade” (BARBOSA, 1956, p. 269).

Bem sucedido o golpe que o elevou ao posto de Vice-Chefe do governo provisório, o que deu uma face aparentemente democrática a um regime dominado pelas forças armadas, pelos positivistas e pela aristocracia paulista, Rui Barbosa fez de tudo para assegurar que a nova ordem exprimisse-se conforme as instituições liberais dos Estados Unidos. Daí porque ele uniu-se aos republicanos conservadores de São Paulo e combateu com todas as suas forças a ameaça da francofilia política representada pelo jacobinismo positivista de Silva Jardim (1860-1891), Aníbal Falcão (1859-1900), Júlio de Castilhos (18601903), Lauro Sodré (1858-1944) e outros, para quem a república verdadeira deveria ser um presidencialismo autoritário e progressista (cf. SODRÉ, 1896; FALCÃO, 1932; CASTILHOS, 1978; JARDIM, 1978). O resultado foi a Constituição provisória, de 22 de junho de 1890, que serviria de anteprojeto aos trabalhos da Constituinte republicana. A Constituição provisória representava uma tentativa consciente de, "sobre as mais amplas bases democráticas e liberais" - como constava de seu preâmbulo -, romper com a moldura intelectual francesa do pensamento brasileiro, substituindo a centralização pelo federalismo, o parlamentarismo pelo presidencialismo, a justiça administrativa pelo poder Judiciário autônomo, o Conselho de Estado e o Tribunal de Cassação por um Supremo Tribunal Federal e o poder Moderador, pelo controle normativo da constitucionalidade.

Embora desconfiado de que o presidencialismo pudesse converter-se num veículo de arbítrio e irresponsabilidade, Rui Barbosa não conseguiu vencer o próprio rigor doutrinário e acomodar parlamentarismo e federalismo. É que ele tinha horror a fazer experimentos: além de envolverem contemporizações com o atraso político, as soluções institucionais híbridas arriscavam o experimento pela falta de precedentes naqueles países cujos costumes políticos ele pretendia reproduzir com a nova ordem política - a Inglaterra e os Estados Unidos. Para ele, o conhecimento essencial para a adequada inoculação institucional do germe da liberdade num ambiente como o brasileiro, que lhe era hostil, era o Direito Internacional Comparado. Como "o caráter geral das grandes nações senhoras de si mesmas” era fornecido por seu "espírito jurídico", o relativismo cultural e a intuição sociológica desempenhavam um papel de pouca ou nenhuma relevância (BARBOSA, 1892, p. 58). Sua esperança era a de que o poder Judiciário fosse capaz de coibir os poderes políticos caso estes pretendessem extrapolar suas atribuições. Emancipado pela nova Constituição e armado com os poderes de julgar os conflitos entre os entes federativos e de declarar a nulidade dos atos normativos e leis dos outros poderes que reputasse incompatíveis com a nova ordem, o Supremo Tribunal Federal deveria fazer, como nos Estados Unidos, as vezes de "um poder neutral, arbitral, terminal, que afaste os contendores, restabelecendo o domínio da constituição” (Barbosa apud DELGADO, 1946, p. 141). Embora seu projeto tenha sofrido algumas modificações durante o processo constituinte, elas não chegaram a desfigurá-lo, 
pelo que Rui Barbosa sempre se referiu à Constituição republicana de 1891 como sua obra.

A postura de Nabuco foi completamente diferente. Desde o início da campanha abolicionista, ele deixara claro que a grande questão da democracia brasileira não era a monarquia, mas a escravidão - ou seja, era social antes de ser política (NABUCO, 1988b, p. 14). Por conta do rebaixamento do povo e da extensão territorial do país, Nabuco achava que, independentemente das fórmulas legais, o regime real do Brasil por muito tempo seria ainda o de uma ditadura de fato; por isso, toda a questão estava em saber se era possível voltála para os excluídos do país. Ora, o processo de abolição da escravatura teria demonstrado inequivocamente "o caráter de governo nacional no mais largo sentido da palavra" assumido pela Coroa, isto é, seu reconhecimento de que a razão nacional identificada com o poder Moderador - espaço de neutralidade do interesse nacional, que pairava acima da política partidária - estava acima das aparências constitucionais (NABUCO, 1983, p. 372). Juntamente com André Rebouças (1838-1898), o Visconde de Taunay (1843-1899) e o Barão do Rio Branco (1845-1912), Nabuco lançou-se numa grande campanha jornalística de sustentação da monarquia, alegando que a campanha republicana havia tornado-se um movimento de desforra da aristocracia rural e do escravismo contra a perspectiva do resgate dos escravos e do povo pela monarquia (GOUVÊA, 1989, p. 365).

Quando do golpe militar de 15 de novembro, no auge do seu prestígio político, Nabuco não apenas se recusou a aderir ao regime de que Rui Barbosa tornara-se o principal líder civil, como resolveu abandonar a vida parlamentar. Para ele, a república não teria como florescer no Brasil para além das meras formas constitucionais desenhadas pelo antigo colega, já que seus bons resultados dependiam da preexistência de uma sociedade democrática guiada pelo espírito público e que era devido à ausência desse requisito sociológico que todas as repúblicas ibero-americanas oscilavam entre a anarquia e a oligarquia. A forma possível do bom governo no Brasil passava pelo predomínio de uma política descolada do particularismo das facções oligárquicas, capaz de garantir o interesse de todos e ampliar o espaço público em benefício do povo. Daí que, para ele, "a monarquia é que era a república" (NABUCO, 2005, p. 109).
Para além dos problemas internos do novo regime, agravados pelo federalismo, Nabuco também estava preocupado com as ameaças representadas pela escalada do imperialismo europeu. Vendo em perigo o Estado nacional pelas sucessões de golpes militares, rebeliões e guerras civis que se sucederam ao 15 de novembro, o autor de O abolicionismo recuou de suas preocupações com a formação nacional para centrar-se no problema da estabilização das instituições, ou seja, da reconstrução do Estado nacional, problema que não havia sido resolvido pela Constituição de 1891 e de que dependia a sobrevivência do Brasil como país livre e independente. No entanto, sua visão de sociólogo político impedia-o de, como Rui Barbosa, aproveitar fórmulas prontas: "Classificar os governos pela sua forma é como a antiga classificação botânica pelas suas formas exteriores. Os governos, como os vegetais, devem ser classificados pelos órgãos da frutificação, frutificação em liberdade, em direito, em honestidade, em progresso" (NABUCO, 1999, p. 73). As instituições políticas deveriam ser elaboradas a partir de um equilíbrio entre o estado real do povo como um todo - e não apenas as aspirações de suas elites alienadas - e os valores que fortaleceriam o Estado na consolidação da nacionalidade e na direção da liberdade democrática (NABUCO, 1949a, p. 37). Embora seu temperamento não o fizesse particularmente interessado em Direito Constitucional, Nabuco continuou a meditar sobre as potencialidades do poder Moderador para pensar como o Estado brasileiro poderia organizar-se como república e escapar da instabilidade do mundo hispânico: "O que a América do Sul precisa", escrevia ele, ao final de Balmaceda, "é um extenso Poder Moderador, um Poder que exerça a função arbitral entre os partidos intransigentes” (idem, p. 135).

Com efeito, todas as suas obras do período são obsessivamente atravessadas pela necessidade de garantir-se esferas estáveis e suprapartidárias de poder, capazes de, a despeito da falta de cultura cívica adequada de suas elites e de sua população, exercer de forma verdadeiramente republicana o seu papel governamental. Ainda que não se tenha detido, nas obras então publicadas, explicitamente sobre o problema institucional brasileiro, suas notas particulares ainda não publicadas, depositadas na Fundação Joaquim Nabuco, são evidências de que o assunto não lhe saía da cabeça, 
na década de 1890: “A República está precisando de quem a organize, como Vasconcelos organizou o Império”, escrevia, “o que fizeram os constituintes foi copiar a Constituição Norte-Americana, e o que se tem feito depois é forçar a nação nesse molde”. A crítica contra a tabula rasa efetuada pela Constituinte visava o seu antigo colega e agora adversário, Rui Barbosa, que, segundo Nabuco, "não era um organizador, um criador de instituições, mas um copista de gênio [...] cujo fundo indestrutível, fixo, era parlamentar, anglo-saxônio, monárquico, prestou-se a dar à República Federativa uma Constituição Americana, como the teria dado qualquer outra que ela quisesse. Era questão de estante, nada mais”; e condenava o procedimento adotado por Rui Barbosa: “organizar a forma republicana entre nós é adaptar as instituições ao gênio do país, o que importa desfazer tudo o que está feito, refazer tudo o que está desfeito" (FUNDAÇÃO JOAQUIM NABUCO, Arquivo Joaquim Nabuco, Mp2, cap. 1, doc. 26a).

Ou seja, para Nabuco, era preciso reorganizar as instituições republicanas à luz das experiências do Império, o que o levava a pensar como, a partir delas, a república brasileira poderia ser organizada: "Eu estimaria hoje uma transação entre o princípio dinástico e o preconceito americano, uma espécie de governo sem prazo marcado, enquanto agradasse; presidência vitalícia de um dos netos do Imperador - parece-me que era o melhor o possível, quem sabe?”. E arriscava, noutra nota, uma organização política republicana parlamentarista, caracterizada, para além do controle normativo da constitucionalidade preconizado por Rui Barbosa, por um poder Moderador exercido por um presidente extraído da realeza ou das forças armadas, auxiliado por um Conselho de Estado, e cuja administração fosse vigiada por um Tribunal de Contas. Os excessos federalistas seriam coibidos por um municipalismo atuante e por uma nova configuração do território nacional, divido em departamentos, transferindo-se a capital para uma ilha a fim de evitar que os golpes que nela tivessem lugar contaminassem automaticamente os estados. Embora parecesse absurda, concluía Nabuco, era esta "a solução mais aproximada que eu posso achar para a quadratura republicana” (idem). O caminho apontado por Nabuco, na década de 1890, seria aquele seguido, décadas depois, por autores como Alberto Torres e Oliveira Vianna.

\section{CONCLUSÃO}

Como se percebe, a despeito de sua comum formação, por questões de temperamento e prioridades, Rui Barbosa e Nabuco estiveram mais ou menos afastados nas causas políticas e sociais a que se dedicaram. Levi Carneiro frisou perfeitamente essa diferença ao destacar que, espírito jurídico, Rui Barbosa era "uma força, quase sobrenatural, a serviço da justiça”, ao passo que, espírito filosófico ou sociológico, Nabuco era um "pensador devotado à felicidade coletiva dos outros homens" (CARNEIRO, 1954, p. 15). Tanto assim, que, afastados do Parlamento, Nabuco refugiar-se-ia na diplomacia, isto é, na defesa dos interesses nacionais para além das vicissitudes da política partidária, e Rui Barbosa, na advocacia, ou seja, no culto dos direitos fundamentais dos cidadãos em que se espelhava seu ideal de justiça. Entretanto, o que interessa não é apenas distinguir os dois políticos, considerados em suas próprias personalidades, mas fazê-lo de maneira a ilustrar uma questão mais ampla, que remonta ao percurso da construção da democracia brasileira. Daí que gostaria agora de remeter ao título deste trabalho: a primeira encruzilhada da democracia no Brasil. O contexto dessa encruzilhada era o de uma nação fraturada: de um lado, por uma elite proprietária, mundo dos senhores e dos patrões que monopolizava a esfera pública; e de outro, por um povo excluído - mundo do trabalho escravizado e dependente, para quem o Estado não existia e cuja única alternativa à miséria era a dominação pessoal exercida pelo senhor ou patrão. Ou seja, é uma nação onde habitavam dois povos, que conviviam e ocasionalmente dialogavam, sem perderem, todavia, a relação de hierarquia e sem reconhecerem-se, no espaço público, como iguais em dignidade. No final do século XIX, a encruzilhada democrática estava, portanto, na possibilidade de escolher entre dois caminhos que deveriam ser paralelos, mas que, naquele momento, na tortuosa estrada da modernização brasileira, eram perpendiculares: reforma política ou reforma social.

O primeiro caminho, o da reforma social, partia de uma concepção democrática mais substantiva e sociológica, que, não podendo conceber a nação dividida em castas, teve de transcender a restrita concepção de nação das elites para também considerar o povo de baixo como parte dela. Esse caminho implicava pensar a democracia a 
partir do conjunto da nação, e não apenas das aspirações exclusivistas das elites de desfrutarem as liberdades dos países civilizados, deixando de fora o restante da sociedade. Nesse quadro, a reforma política só poderia acompanhar a social à medida em que fosse compatível com ela - quadro que, para Nabuco, não se apresentava em 1889. Pensar aqui, por sua vez, a organização institucional da democracia, implicava relativizar minimamente os eventuais tipos ideais de Estado democrático, a fim de considerar as experiências de outros países e as próprias. Ou seja, que o caminho institucional da democracia passava pela consideração das especificidades nacionais e não se poderia deixar aprisionar excessivamente por modelos abstratos. Esse foi o caminho escolhido por Nabuco. Ele só se permitiu colaborar com a república dez anos depois, e, mesmo assim, na qualidade de diplomata - posto que lhe permitia cumprir o seu dever de servir ao Brasil, mantendo-se acima das formas de governo e das disputas oligárquicas da política interna: "Eu quero viver até o fim, monarquista”, escreveu ele, “mas quero morrer, reconciliado com os novos destinos do meu país. Nada podendo fazer pelo seu espírito, quero fazer pelo seu corpo, pelo seu território, e a fidelidade ao território, à integridade nacional, já é a divisa de uma geração" (FUNDAÇÃO JOAQUIM NABUCO, Arquivo Joaquim Nabuco, Mp2, cap. 1, doc. 24a). Nabuco não foi o primeiro a apontar o caminho, nem foi o último a dizer que a democracia liberal no Brasil passava por caminhos aparentemente não-liberais. Continua, entretanto, o primeiro da galeria pela lucidez e pela penetração de sua análise social e política, até hoje não superada.

O outro caminho, o da reforma política, partia de uma concepção liberal formalista de democracia e era defendido pelo primeiro povo ou o povo de cima. Esse povo era uma aristocracia em relação ao povo de baixo, mas pelo fato de que restringia a esfera pública à sua própria classe social, a ponto de só ver a si mesmo no espelho da nação, ele se pensava uma democracia e, como tal, queria tomar o poder e governar conforme seus interesses. Democrática para as elites agrárias que queriam eliminar a autonomia do Estado, a opção do povo de cima era evidentemente oligárquica, considerando-se o conjunto da nação. Na falta de reformas sociais, seria possível à aristocracia rural, em nome da modernidade política, democrática e republicana, converter o Estrado num instrumento de classe, preservando a hierarquia e as distinções face ao segundo povo ou o povo de baixo. Foi esse o caminho trilhado por Rui Barbosa, vitorioso com a consolidação da I República. Embora ele não pertencesse à aristocracia rural, seu formalismo jurídico-político e sua concepção ilustrada de nação reduziram-lhe a tal ponto o horizonte de expectativas, que o levaram involuntariamente a ajudar a lavoura na liquidação de um regime de governo que seria sempre o de sua predileção e a servir depois de arquiteto institucional da aristocrática república dos senhores de engenho e fazendeiros de café. Entretanto, suas ilusões com o novo regime duraram pouco tempo (cf. LYNCH, 2007b). Ao tornar-se o símbolo do Direito e da justiça, contra a corrupção e as oligarquias da república, ao pregar a reforma da própria obra para chegar, enfim, à reforma social e resgatar a dimensão esquecida da democratização brasileira, Rui Barbosa teria a oportunidade de redimir-se e de encontrar na história um lugar à altura do seu talento - ainda que trinta anos depois de Nabuco.

Christian Edward Cyril Lynch (clynch3@hotmail.com) é Doutor em Ciência Política pelo Instituto Universitário de Pesquisas do Rio de Janeiro (Iuperj), Pesquisador da Fundação Casa de Rui Barbosa (FCRB) e Professor do Programa de Pós-Graduação em Sociologia e Direito da Universidade Federal Fluminense (UFF).

\section{REFERÊNCIAS BIBLIOGRÁFICAS}

ANDRADA E SILVA, J. B. 1978. Discursos parlamentares. Brasília : Senado Federal.

BAGEHOT, W. 2003. The English Constitution. $10^{\text {th }}$ ed. s/l : Project Gutenberg. Disponível em : http://www.gutenberg.org/etext/4351. Acesso em : 15.mar.2008.
BARBOSA, R. 1892. O Estado de sítio : sua natureza, seus efeitos, seus limites. Rio de Janeiro : Companhia Impressora.

. 1932. Correspondência. São Paulo : Saraiva. 
1950. Teoria política. Rio de Janeiro : W. M. Jackson.

1952. Obras seletas. Tribuna parlamentar. V.I : Império. Rio de Janeiro : Fundação Casa de Rui Barbosa.

1956. Tribuna parlamentar - República. T. V. Rio de Janeiro : Fundação Casa de Rui Barbosa.

1978. República : teoria e prática. Textos doutrinários sobre direitos humanos e políticos consagrados na primeira constituição republicana. Petrópolis : Vozes.

1988. A emancipação dos escravos. Rio de Janeiro : Fundação Casa de Rui Barbosa.

CARNEIRO, L. 1954. Dois arautos da democracia : Rui Barbosa e Joaquim Nabuco. Rio de Janeiro : Fundação Casa de Rui Barbosa.

CARVALHO, M. A. R. 1998. O quinto séculoAndré Rebouças e a Construção do Brasil. Rio de Janeiro : Revan.

CASTILHOS, J. 1978. Idéias políticas de Júlio de Castilhos. Rio de Janeiro : Senado Federal.

COSER, I. J. A. 2005. Civilização e sertão no pensamento social brasileiro do século XIX. Caderno CRH, Salvador, v. 18, n. 44, p. 237248, maio-ago. Disponível em : http:// w w w. c a d e r n o c r h. u f b a. b r / viewarticle.php?id=51\&layout=abstract. Acesso em : 15.mar.2008.

DELGADO, L. 1946. Rui Barbosa - tentativa de compreensão e síntese. Rio de Janeiro : J. Olympio.

FALCÃO, A. 1932. Fórmula da civilização brasileira. Rio de Janeiro : Guanabara.

GONÇALVES, J. F. 2000. Rui Barbosa : pondo as idéias no lugar. Rio de Janeiro : Fundação Getúlio Vargas.

GOUVÊA, F. C. 1989. Joaquim Nabuco entre a Monarquia e a República. Recife : Fundação Joaquim Nabuco.

JARDIM, A. S. 1978. Propaganda republicana. Rio de Janeiro : Fundação Casa de Rui Barbosa.

JAVARI, B. (org.). 1993. Império brasileiro : falas do trono, desde o ano de 1823 até o ano de 1889, acompanhadas dos respectivos votos de graça da câmara temporária e de diferentes informações e esclarecimentos sobre todas as sessões extraordinárias, adiamentos, dissoluções, sessões secretas e fusões com um quadro das épocas e motivos que deram lugar à reunião das duas câmaras e competente histórico, coligidas na secretaria da Câmara dos Deputados. Rio de Janeiro : Itatiaia.

LASKI, H. J. 1973. O liberalismo europeu. São Paulo : Mestre Jou.

LYNCH, C. E. C. 2005. O discurso político monarquiano e a recepção do conceito de poder Moderador no Brasil (1822-1824). Dados, Rio de Janeiro, v. 48, n. 3, p. 611-654, set.

2007a. O momento monarquiano - O conceito de poder Moderador e o debate político brasileiro do século XIX. Rio de Janeiro. Tese (Doutorado em Ciência Política). Instituto Universitário de Pesquisas do Rio de Janeiro. Disponível em : http://www.iuperj.br/biblioteca/ teses/tese\%20christian\%20lynch.pdf. Acesso em : 15.mar.2008.

2007b. A utopia democrática - Rui Barbosa entre o Império e a República. In : SENNA, M. (org.). Rui Barbosa em perspectiva : seleção de textos fundamentais. Rio de Janeiro : Fundação Casa de Rui Barbosa.

MATTOS, I. R. 1994. O tempo saquarema - a formação do Estado imperial. Rio de Janeiro : Acess.

MORAN, E. F. 1972. Rui Barbosa e a abolição. Rio de Janeiro : Fundação Casa de Rui Barbosa.

NABUCO, J. 1949a. Balmaceda - A intervenção estrangeira durante a Revolta de 1893. São Paulo : Progresso.

1949b. Cartas aos amigos. V. II : (18981910). São Paulo : Progresso.

1983. Discursos parlamentares. Brasília : Câmara dos Deputados.

1988a. O abolicionismo. Rio de Janeiro : Vozes.

1988b. Campanha abolicionista do Recife. Recife : Massangana.

1999. Por que continuo a ser monarquista. In : ANDRADE, M. C.(org.) A Abolição e a República. Recife : UFPE. 
2005. Diários. V.II : 1889-1910. Recife : Fundação Joaquim Nabuco.

PORTO, W. C. 2002. O voto no Brasil. Da colônia à $6^{a}$ República. $2^{\mathrm{a}}$ ed. Rio de Janeiro : Topbooks.
SIMON, J. 1868. La politique radicale. Paris : Librarie Internationale.

SODRÉ, L. 1896. Crenças e opiniões. Belém : Diário Oficial.

VIANA FILHO, L. 1949. Rui Barbosa e Nabuco. Rio de Janeiro : J. Olympio.

\section{OUTRAFONTE}

BRASIL. Câmara dos Deputados. Anais da Câmara dos Deputados. Disponível em : http:// imagem.camara.gov.br/diarios.asp. Acesso em : 3.maio.2008.

FUNDAÇÃO CASA DE RUI BARBOSA. 1988
[1878]. Atas do Congresso Agrícola do Rio de Janeiro. Fac-símile. Rio de Janeiro.

FUNDAÇÃO JOAQUIM NABUCO. Arquivo Joaquim Nabuco. Mp2, cap. 1, doc. 24a; Mp2, cap. 1, doc. 26a. Recife. 
BRAZILIAN DEMOCRACY AT ITS FIRST CROSSROADS: THE CASES OF RUI BARBOSA AND JOAQUIM NABUCO

\section{Christian Edward Cyril Lynch}

ABSTRACT: The advent of liberal-democratic discourse in Brazil occurred at the moment in which oligarchic forces brought together elements able to contest the Crown's preeminence over imperial political structures. However, the crown's position on the abolition of slavery generated a short circuit in the way in which, until this moment, liberalism and democracy had been articulated. In this regard, the contrast between Rui Barbosa and Joaquim Nabuco's positions is exemplary. Through a normative universalist position, Rui Barbosa followed liberal doctrine, running the risk of handing power over to the oligarchies, whereas Nabuco, through sociological analysis, advocated the Crown's "illustrated despotism" which he believed would be capable of breaking up oligarchic power and implementing necessary social reforms. Our article, through direct recourse to primary sources of documentation, analyzes this debate. Its purposes are not primarily to produce a detailed discussion of the differences between the two politicians through consideration of their individual personalities but to illustrate a broader issue that deals with the trajectory of building democracy in Brazil. Comparison of the discourse of both politicians illustrates the dilemma of placing priority on political or social reform within a context in which the two seem to be clearly mutually exclusive. Furthermore, the debate enables us to understand the impasses that emerge in the trajectory of democracy in Brazil, squeezed between oligarchic liberalism and an authoritarian broadening of public space.

KEYWORDS: democracy; liberalism; modernization; Rui Barbosa; Joaquim Nabuco; political reforms; social reforms.

\section{LE PREMIER CONFLIT DE LA DÉMOCRATIE BRÉSILIENNE : LE CAS DE RUI BARBO- SA ET DE JOAQUIM NABUCO}

Christian Edward Cyril Lynch

L'avènement du discours libéro-démocratique au Brésil a eu lieu au moment où les forces oligarchiques réunissent assez d'éléments pour contester la prépondérance de la Couronne sur les structures politiques impériales. Cependant la promotion de l'abolition de l'esclavage par la Couronne a provoqué un court-circuit dans la manière dont le libéralisme et la démocratie étaient articulés. Dans ce sens, le contraste entre la conduite de Rui Barbosa et de Joaquim Nabuco sont remarquables. A partir d'une perspective universaliste normative, Rui Barbosa a suivi le manuel doctrinaire libéral au risque de rendre le pouvoir aux oligarchies, tandis que, suivant une analyse sociologique, Nabuco a prôné le « despotisme éclairé » de la Couronne, capable, selon lui, de briser le pouvoir oligarchique et mettre en oeuvre les réformes sociales nécessaires. Dans cet article, qui se sert directement de la documentation primaire, on analyse ce débat, moins pour explorer les différences entre les deux politiciens, considérés comme personnalités individuelles, que pour illustrer une question plus importante, qui remonte au parcours de construction de la démocratie brésilienne. La comparaison entre les discours de Rui Barbosa et Joaquim Nabuco illustre le dilemme entre rendre prioritaire des réformes politiques et rendre prioritaire des réformes sociales, dans un contexte dans lequel elles semblaient nettement s'opposer. Le débat aide à saisir les difficultés de la trajectoire démocratique au Brésil, coincée entre le libéralisme oligarchique et l'élargissement autoritaire de l'espace public.

MOTS-CLÉS : démocratie ; libéralisme ; modernisation ; Rui Barbosa ; João Nabuco ; réformes politiques ; réformes sociales. 